\title{
MODERN CLIMATE CHANGE AS A FACTOR IN THE DEVELOPMENT OF THE LANDSCAPES OF CENTRAL RUSSIAN FOREST-STEPPE (ON EXAMPLE OF KURSK REGION)
}

DOI: http://dx.doi.org/10.18509/GBP.2019.11

UDC: 551.583.1:550.7(470)

\author{
Lukashova Olga Pavlovna, \\ Bogatyreva Margarita Alekseevna, \\ Dmitrova Elena Sergeevna \\ Kursk state University, Russia
}

\begin{abstract}
The paper reveals the basic laws of spatial and temporal distribution of the main meteorological parameters and calculated climatic parameters characterizing the hydrothermal regime of the Kursk region. the maps of climatic zoning of the territory of the region on the basis of dynamics of indicators of climatic characteristics are developed. Research methods were complex: analysis of scientific and reference literature, observation and measurement of climatic parameters in the field, the method of cartographic, mathematical and statistical used for processing and presentation of the materials.
\end{abstract}

Key words: climate, hydrothermal regime, climatic zoning,

\section{INTRODUCTION}

Assessment of current and forecast expected climate change is one of the priority problems in the earth Sciences. Recent developments are taking place at both the global and regional levels. The dynamics of such climatic parameters as temperature and precipitation determine the conditions of landscape change. Of particular interest is the dynamics of hydrothermal parameters. The study of spatial and temporal variability of air temperature and precipitation is of great importance for the development of regional scenarios of future climate change and for solving a number of practical problems related to the rational use of agro-climatic resources.

Meteorological observations in the Kursk region are carried out on the territory of all landscape areas. However, despite the fact that the climate and landscapes of the Kursk region themselves are studied and described quite well, in the works on landscape studies mainly still used climatic characteristics of half a century ago. In recent years, studies have been conducted on the climate of landscapes, but in the Kursk region such studies were not.

Modern climate changes in the forest-steppe zone do not lead to a significant transformation of the landscape structure of the territory. What determines the stability of forest-steppe landscapes to the changes. Therefore, the assessment of the impact of climate change on the landscape structure of the region is relevant and is not only theoretical, but also of practical interest. 


\section{STUDY REGION, OBJECTS, AND METHODS}

The work is based on the statistical data of climatic changes in forest-steppe landscapes of Kursk region for 1950-2016 from the funds of the Central black earth Department for Hydrometeorology and environmental monitoring. In the course of the research the following methods were used: the method of field research, studies were carried out at key sites of the Kursk biosphere station of the Institute of geography of the Russian Academy of Sciences; the method of mathematical modeling and statistical processing, including a set of methods of numerical data processing. Mathematical and statistical data processing was carried out with the help of statistical analysis software package MSExel;. the method of remote sensing (aerospace method), provides a comprehensive view of the landscape structure and allows you to track changes in the components of the biosphere.

\section{RESEARCH RESULT}

Kursk region is located in the middle latitudes of the temperate zone in the center of the East European plain, on the South-Western slopes of the Central Russian upland, within the forest-steppe zone. the region has long had favorable conditions for the growth of both forest and steppe vegetation. Currently, most of the region is plowed and occupied by crops. Forest-steppe communities are fully dependent on natural climatic and meteorological conditions on the one hand, and long-term anthropogenic impact on the other hand. Now about the forest-steppe landscapes of Kursk region can be said in the past time, because they are almost unchanged preserved in an area of less than $1 \%$ of the territory (reserve, natural monuments). In 1935, the Central Chernozem reserve was created on the territory of Kursk region. Professor V. V. Alekhine. He currently has six divided sections: Musketeers, Cossack, Bukreeva the Barm, Barkalova the Scene, the Floodplain of the Psel river and covers an area of over 5 hectares, the Reserve is a benchmark of landscapes forest-steppe. In General, in the region we have a complex mosaic of landscape formations: not changed by man landscapes( protected areas); poorly changed by man landscapes, preserving the ability to restore the original structure; (forest tracts of natural and anthropogenic origin, deposits, steppe pastures, dumps with a newly formed ecosystem); irreversibly changed by man landscapes (quarry-dump complexes, agricultural land, land with a high degree of development of ravine erosion, land settlements, etc.) [5].

According to the peculiarities of the main climatic features (temperature, air humidity, amount of precipitation), the climate of Kursk region is moderately continental, the main differences of which are: a large annual temperature amplitude; a relatively long moderately cold winter with a stable snow cover and blizzards; Sunny, warm, sometimes hot and dry summers; the predominance of summer precipitation over winter $[1,10]$. For modern forest-steppe landscapes characterized by periodic drying of oak trees, which is a consequence of sharp deviations of climatic factors from the average long-term values. According to fgbi "Central Chernozem UGMS" such dangerous hydrometeorological phenomena as soil and atmospheric droughts were repeatedly observed in most of the region in the third decade of July-the first decade of August. Subsequently, extremely low winter temperatures contribute to a significant weakening of trees [2].

The study of climate change focuses on two main elements-temperature and moisture. Meteorological stations of Kursk region located in the North (ponyri); in the East (Tim): 
in the South (Oboyan); in the West (Rylsk) and in the center of the region (Kursk) were chosen for the analysis of changes in climatic parameters.

Air temperature is one of the most important elements of climate. The main characteristics of the temperature regime are the average annual and average monthly air temperature. According to "Central Chernozem UGMS" in recent years there has been an increase in average annual temperatures and average temperatures of many months. The highest growth was recorded in the cold half of the year. The average annual air temperature has increased by $0.6-0.8{ }^{\circ} \mathrm{C}$ since the mid-20th century at all stations. Long-term average air temperature of the winter months over the past decade, exceeding the multiyear average. The winter months have become warmer by $1-1.5^{\circ} \mathrm{C}$. So in the Kursk region there is a tendency of growth of average annual temperatures, mainly due to the winter months[7].

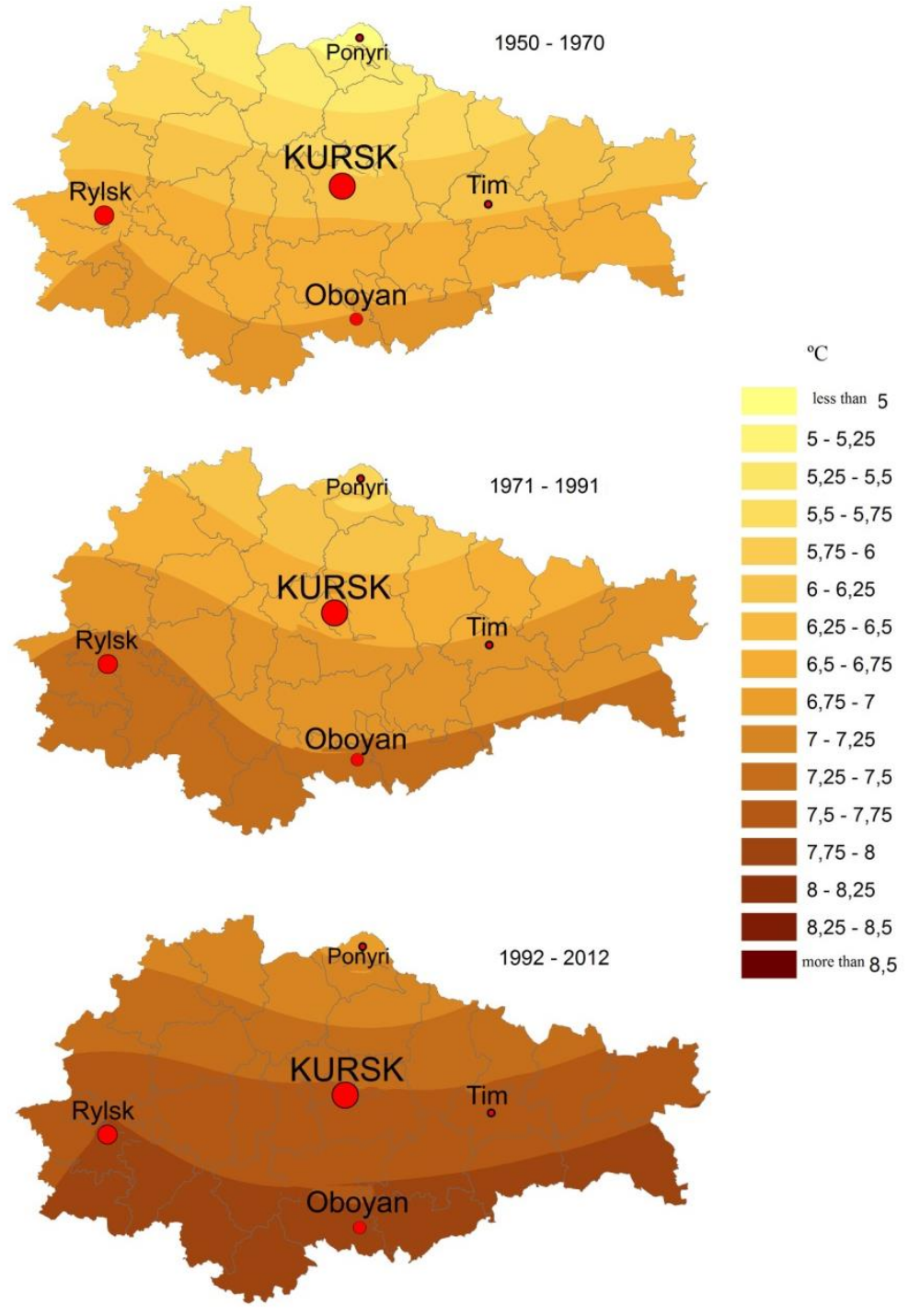

Figure 1. Change in average annual temperature

After analyzing the annual average of the temperature regime in the Kursk region, revealed that these figures are significantly above the average. The long-term average air temperature has changed significantly in the winter. The trend of changes in average annual temperatures during the study period was positive throughout the region. The greatest growth has been observed since the 90s [7] (figure 1). 
The dynamics of changes in annual and seasonal precipitation within the Kursk region in the period 1950-2015 revealed the following features. In most of the region, the trend in precipitation was positive during the study period. Geographically within the region, the West remains the most humid, while the East is less humid [7] (figure 2).
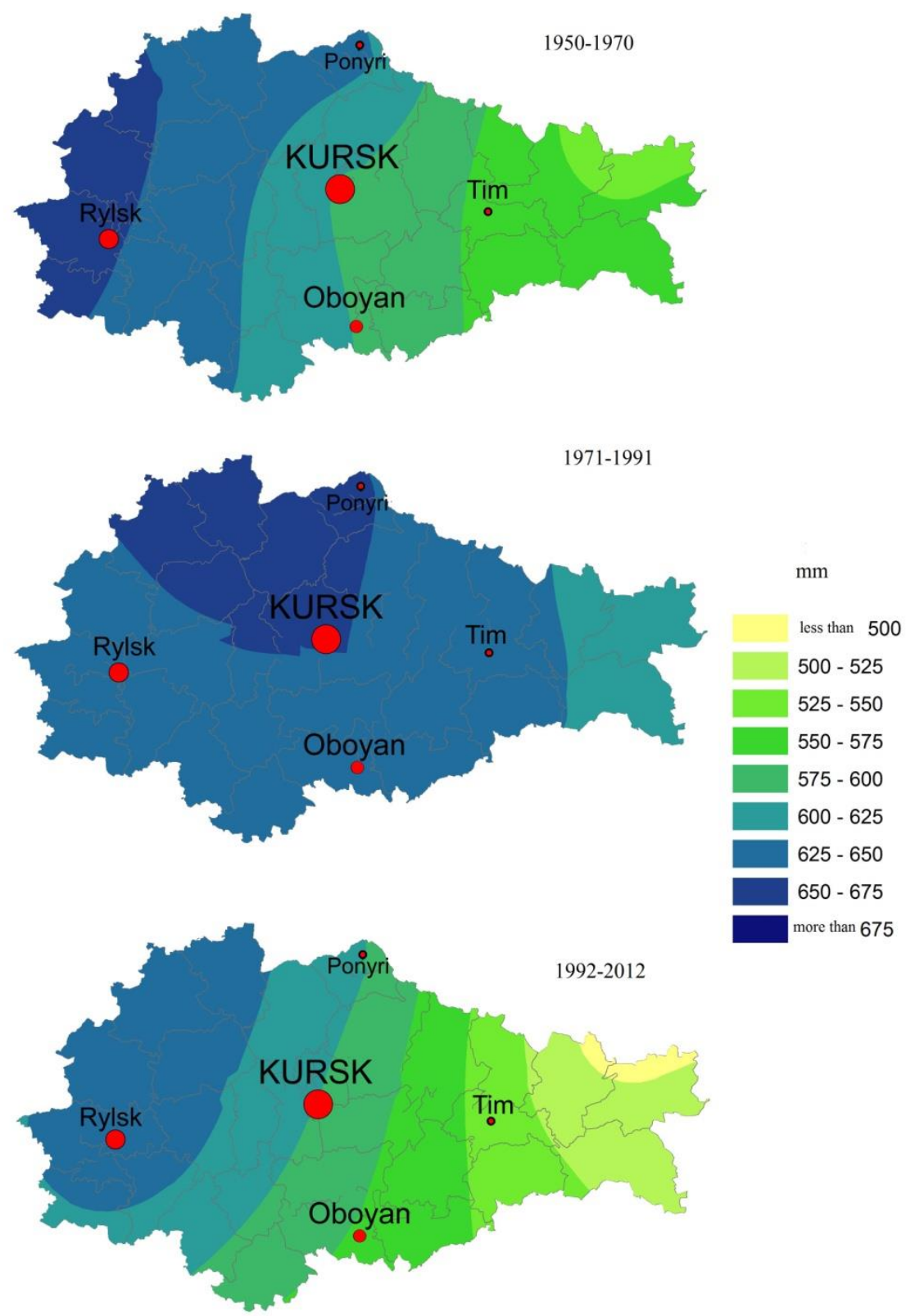

Figure 2. Change in average annual precipitation

Having analyzed the dynamics of changes in precipitation in the forest-steppe landscapes of the Kursk region for the period from 1950 to the present time, multidirectional trends in the dynamics of seasonal indicators are also revealed. So the main rise of winter precipitation occurred in 1965-1970 years. The amount of precipitation in winter over the past decade has been unstable, as evidenced by the cyclical power of snow cover, its density and water content. According to observations, the last decade was not marked by a sharp change in the power of snow cover, despite the frequency of warm and cold 
winters. The number of winters with low snow storage has increased to a greater extent [3].

A significant contribution to the increase in the total amount of precipitation is made by precipitation of the warm period. A characteristic feature of the changed moisture was an increase in the probability of precipitation. The number of days with heavy rains has increased $[4,9]$.

Dangerous hydrometeorological phenomena such as droughts and dry winds have been repeatedly recorded in the region. According to the "Information about hazardous natural hydrometeorological phenomena observed in the territory of the activities of the "Centralchernozemnoe UGMS" similar phenomena have been observed in most parts of the region in the 3 decade of July -1 decade of August. That is, the duration of dry periods of 2-3 decades by the beginning of the 21 st century increases, which can adversely affect vegetating plants and lead to episodic soil and atmospheric droughts. Also in the studied period since 1996 there has been an increase in days with severe heat. Fire danger was recorded on more than $70 \%$ of the territory in the beginning of 2000 and of course in 2010.[6, 8] Adverse effects of climate change may affect the trend of increasing the frequency of dangerous hydrometeorological events.

\section{SUMMARY}

On the territory of the Kursk region at the turn of 20-21 centuries manifested warming. The average annual temperature is much higher than the average long-term data. This is primarily due to the steady increase in temperature, mainly due to the winter months. With regard to moisture, there was no clear trend. The increase in moisture is provided due to the growth of heavy rain. The negative effects of climate change may be reflected in the trend of increasing the frequency of dangerous hydrometeorological events. Trends in the main climate parameters in the second half of the twentieth century persisted in the first years of the new century.

\section{REFERENCES}

[1]The Climate Of Kursk. Edited by Dr. geogr. science N. P. Tsykalo. L.: Gidrometeoizdat. 1984. $-112 \mathrm{p}$.

[2] Information about hazardous natural hydrometeorological phenomena observed in the territory of the activities of the fgbi "Central-chernozemnoe UGMS" in 2000-2013 Kursk, 20012014.

[3] Lukashova O. P., Lunin, V. N. Regional effects of global climate change// Snow cover as an indicator of climate change. Voronezh, 2012. - P. 75.

[4] Second assessment report of Roshydromet on climate change and its consequences in the Russian Federation. - Moscow: Roshydromet, 2014. - 1008 p.

[5] Lukashova O. p. Dynamics of variability of natural and climatic conditions of the territory as a factor of stability of landscapes of forest-steppe (on the example of Kursk region). Materials of the International scientific conference "LANDSCAPE GEOGRAPHY IN the XXI CENTURY". Edited by E. A. Pozachenyuk. Publisher: limited liability Company "publishing house "Arial" (Simferopol). - 2018. - P. $296-298$.

[6] Bogatyreva, M. A. Dynamics of manifestation of natural hazards on the territory of Kursk region during the last 50 years." Collection of materials of the 9th international youth schoolconference "Meridian": Methods and means of research of nature and society. Moscow: IG RAS, 2016. - P. 22-24. 
[7] Bogatyreva M. A. Manifestation of modern climate change in the Kursk region. Journal "Central scientific Bulletin". Volume 1. Number 16. Pushkino: publishing house RHYTHM, 2016. - P. 37-38.

[8] Smolyaninov V.M., Starodubtsev P.P. Complex soil improvement and land irritation in the Central Black Soil Region: State, conditions for development. Voronezh: Istoki, 2011. 179 p.

[9] Goneev I.A., Lukashova O.P., Bogatyreva M.A. Changes of modern Central Russian Upland landscapes caused by natural factors (through the example the Kursk region). The collection includes the 3d International Scientific-Practical Conference on the Humanities and the Natural Science by SCIEURO in London, 2015 - P. 144-154.

[10] Lebedev M. G., Krymskaya O. V. Ecology of the region. Part 3. Ecological climatology and climatic resources of the Central black earth region. Textbook. Ed. by A. N. Petina. - Belgorod: Publishing house of BelSU, 2008. - 196 p. 